\title{
Epiphytic flora on Gelidium corneum (Rhodophyta: Gelidiales) in relation to wave exposure and depth
}

\author{
Endika Quintano, Isabel Díez, Nahiara Muguerza, Alberto Santolaria, José María Gorostiaga \\ Department of Plant Biology and Ecology, Faculty of Science and Technology, University of the Basque Country UPV/ \\ EHU, PO Box 644, E-48080 Bilbao, Spain. E-mail: endika.quintano@ehu.es
}

\begin{abstract}
Summary: The canopy-forming macroalga Gelidium corneum (Hudson) J.V. Lamouroux plays a major role in the functioning of the subtidal ecosystem of the Cantabrian Sea (northern Spain). Despite its importance, little is known about the factors that may potentially affect the distribution pattern of its epiphytic flora. Here we examine two indirect factors: coastal orientation (N and NW) and depth ( 3 and $7 \mathrm{~m}$ ), as proxies for wave exposure and light availability, respectively. We test their effects on the total epiphytic load, alpha diversity (species richness, Shannon, Simpson and evenness measures) and multivariate structure of the epiphytic flora growing on $G$. corneum in subtidal waters off the Basque coast. Plocamium cartilagineum, Dictyota dichotoma and Acrosorium ciliolatum were found to be the most common epiphytes. Significant interactive effect of coastal orientation and depth were observed for species composition and abundance of epiphytic flora. Increased wave exposure resulted in a lower epiphyte load and a less diverse community, suggesting that under high hydrodynamic conditions epiphytes were more likely to become dislodged from hosts. However, light availability only had a significant effect on the distribution of epiphytes below a certain threshold of wave action, with the epiphytic load being 30-40\% greater on shallow bottoms.
\end{abstract}

Keywords: epibionts; host frond; light availability; spatial variability; macroalgae; wave action.

Flora epífita de Gelidium corneum (Rhodophyta: Gelidiales) en relación a la exposición al oleaje y la profundidad

Resumen: El alga formadora de copa Gelidium corneum (Hudson) J.V. Lamouroux tiene un papel fundamental en el funcionamiento de los ecosistemas submareales del mar Cantábrico (norte de España). A pesar de su importancia, se sabe poco sobre los factores que afectan a la distribución de su flora epífita. En este estudio, examinamos dos factores indirectos: la orientación de la costa ( $\mathrm{N}$ y NO) y la profundidad (3 y $7 \mathrm{~m}$ ), como factores representativos de la exposición al oleaje y la disponibilidad de luz, respectivamente. Este estudio testa sus efectos sobre la carga total de epífitos, la alfa-diversidad (riqueza de especies, Shannon, Simpson y equitatividad) y la estructura multivariable de la flora epífita que crece sobre G. corneum en las aguas submareales de la costa vasca. Los epífitos más comunes fueron Plocamium cartilagineum, Dictyota dichotoma y Acrosorium ciliolatum. Se observó un efecto interactivo de la orientación de la costa y la profundidad para la composición de especies y la abundancia de la flora epífita. En las localidades con mayor exposición al oleaje la carga epífita era menor y la comunidad menos diversa, sugiriendo que bajo condiciones de un elevado hidrodinamismo los epífitos eran más susceptibles de ser desprendidos de su hospedador. Sin embargo, la disponibilidad de luz solo tuvo un efecto significativo en la distribución de los epífitos por debajo de ciertos umbrales de la acción del oleaje, siendo la carga de epifitos un 30-40\% mayor en los fondos someros.

Palabras clave: acción del oleaje; disponibilidad de luz; epibiontes; fronde hospedador; macroalgas; variabilidad espacial.

Citation/Como citar este artículo: Quintano E., Díez I., Muguerza N., Santolaria A., Gorostiaga J.M. 2015. Epiphytic flora on Gelidium corneum (Rhodophyta: Gelidiales) in relation to wave exposure and depth. Sci. Mar. 79(4): 479-486. doi: http:/l dx.doi.org/10.3989/scimar.04239.08B

Editor: E. Ballesteros.

Received: March 13, 2015. Accepted: July 13, 2015. Published: October 9, 2015.

Copyright: (0) 2015 CSIC. This is an open-access article distributed under the Creative Commons Attribution-Non Commercial Lisence (by-nc) Spain 3.0.

\section{INTRODUCTION}

Epiphytism is a widespread strategy in marine benthic communities on rocky bottoms where the competi- tion for space is high (Rindi and Guiry 2004, Belegratis et al. 1999). Macroalgae provide an ideal primary substratum for the growth of epiphytic algae (Lutz et al. 2010), which significantly contribute to primary pro- 
ductivity (Belegratis et al. 1999) and, in turn, provide habitat for other organisms (Karez et al. 2000). Epiphytism entails both benefits and disadvantages for the host plant (Wahl 1989). In general, the detrimental effects of epiphytes are indirect (Fricke et al. 2011). They increase drag on hosts, increasing their risk of breakage and dislodgement, particularly in hydrodynamically stressful environments (Anderson and Martone 2014). Furthermore, growth rates and reproductive output of heavily epiphytized hosts may decrease as a result of the reduction in irradiance reaching the frond (SandJensen 1977) and the partial nutrient depletion of water after its passage through the epiphytic layer (Muñoz et al. 1991). Favourable consequences of epiphytism have also been postulated, including herbivore avoidance and protection against desiccation for intertidal hosts (Anderson and Martone 2014).

Gelidium corneum (Hudson) J.V. Lamouroux (formerly G. sesquipedale) is a very important benthic primary producer in the Cantabrian Sea (Rico and Fredriksen 1996, Gorostiaga et al. 1998, Díez et al. 2003) and forms extensive stands at depths down to $9-15 \mathrm{~m}$ in the subtidal zone off the Basque coast (Gorostiaga 1995, Borja et al. 2004). This canopyforming species plays an important ecological role by providing habitat and shelter for many other organisms (Borja et al. 2004, Bustamante et al. 2014). The algae Dictyota dichotoma, Plocamium cartilagineum and Asparagopsis armata (Santos 1994) and the bryozoans Electra pilosa and Scrupocellaria spp. (Bustamante et al. 2014) have been reported as its main epibionts. The seasonal pattern of $G$. corneum growth substantially influences the development of the epiphytic load. This perennial species with apical growth (about 7-8

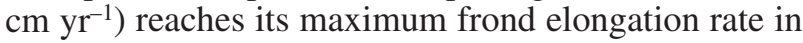
late spring and summer (Gorostiaga 1994). Under the high light availability of this period, G. corneum forms a dense canopy as a result of the fast process of frond branching, which favours the settlement and growth of epiphytes (Gorostiaga 1994, Santos 1994). In autumn and winter a considerable loss of branches occurs due to the effect of storms, resulting in a decrease in the standing stock of G. corneum (Gorostiaga 1994) and in its epiphytic load.

G. corneum used to be the main raw material for agar extraction along the Atlantic shores of Spain, Portugal and Morocco, providing these countries with almost $50 \%$ of the world harvest in the 1980s (McHugh 1991). In the particular case of the Basque coast, G. corneum was only exploited by scuba diving in the 1970s and between 1992 and 1999 (Borja et al. 2013). However, since the turn of the $21^{\text {st }}$ century many $G$. corneum beds have suffered a significant decline on several coastal stretches of the Basque coast (Díez et al. 2012, Borja et al. 2013), where this macrophyte exhibits morphological (Díez et al. 2012) and biochemical (Quintano et al. 2013) symptoms of stress. It has been suggested that climatedriven factors such as increased seawater temperature in combination with changes in local factors that include light and nutrients availability and wave energy are involved in the declines of G. corneum beds (Díez et al. 2012, Borja et al. 2013). Since epiphytism potentially affects the growth and survival of $G$. corneum and may interact with other stressors, information about factors affecting epiphyte development is valuable. Likewise, epiphyte composition and abundance on $G$. corneum are liable to change according to environmental conditions, and thus this particular flora can play a greater role as a bioindicator (i.e. stress symptoms), as has been reported for other macrophytes (Russell et al. 2005, Giovannetti et al. 2010).

Wave exposure and irradiance have long been recognized as major factors in regulating the distribution of algae (Lüning 1990). In this regard, epiphyte growth and colonization are generally negatively affected by increased wave energy, whereas increased light favours epiphyte development (Michael et al. 2008). In this study we examine two indirect factors, coastal orientation (north and northwest; $\mathrm{N}$ and NW) and depth (3 and $7 \mathrm{~m}$ ), as proxies for wave exposure and light availability, respectively. We test the effects of these two factors and their interaction on the total epiphytic load, alpha diversity (species richness, Shannon, Simpson and evenness measures) and multivariate structure of the epiphytic flora growing on the red alga $G$. corneum in subtidal waters off the Basque coast. We expected the abundance and diversity of epiphytes to be negatively correlated with wave exposure (higher loads in north facing coastal stretches) and positively correlated with light intensity (higher loads on shallow bottoms).

\section{MATERIALS AND METHODS}

\section{Study area}

The Basque coast is situated in the southernmost part of the Bay of Biscay (northern Spain). The study was carried out on the coast of Bizkaia (western Basque coast) (Fig. 1), which is $108 \mathrm{~km}$ long (Díez et al. 2003) and is dominated by rocky substrata (Chust et al. 2011). The Basque coast is exposed to large fetches where swell mainly comes from the WNW and NW (González et al. 2004), with mean significant wave heights (Hs) of 1.5 and $2.5 \mathrm{~m}$ during summer and winter, respectively (Liria et al. 2009).

\section{Data collection}

As a consequence of the prevailing NW swell in the study area, coastal stretches facing this direction are more exposed than those facing $\mathrm{N}$, which are in turn more exposed than those facing NE. G. corneum thrives mainly in exposed (N) to very exposed (NW) coastal stretches (Borja et al. 2004). Therefore, in order to represent two hydrodynamical conditions, three locations were randomly selected with the two coastal orientations where G. corneum was present: north (N) and northwest (NW) (Fig. 1). The classification of the sampling locations into two degrees of wave exposure was supported by the type of canopy vegetation found there, which acts as a good indicator of hydrodynamics in the study area (Díez et al. 2003). Bottoms at very exposed locations were dominated 


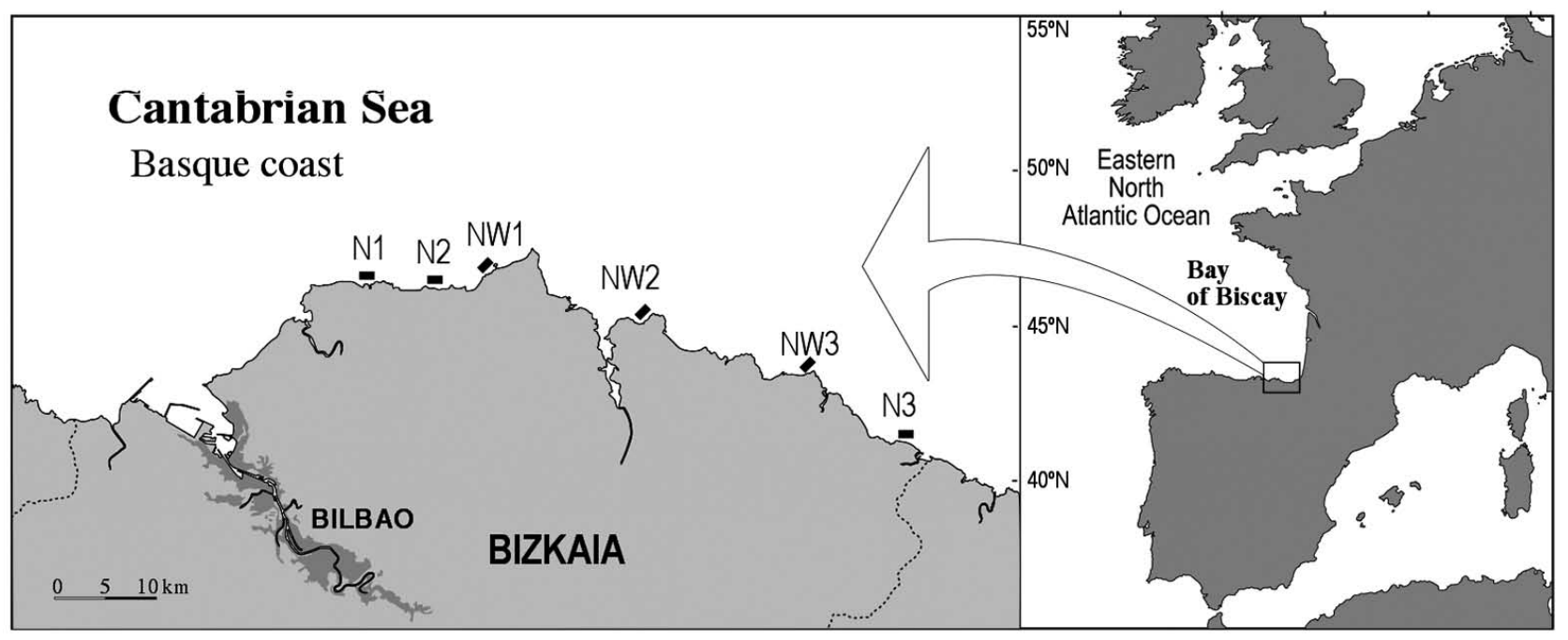

Fig. 1. - Study area. Layout of the six transects along the coast of Bizkaia (western Basque coast). North-facing locations: Armintza (N1); Gaviota (N2); Ondarroa (N3). Northwest facing locations: Bakio (NW1); Cape Ogoño (NW2); Cape Lekeitio (NW3).

by a monospecific canopy of $G$. corneum, whereas in exposed sites Cystoseira baccata was co-dominant (Díez et al. 2003). The N-facing locations were Armintza (N1) $\left(43^{\circ} 26^{\prime} 39^{\prime \prime} \mathrm{N}, 2^{\circ} 54^{\prime} 53^{\prime \prime} \mathrm{W}\right)$, Gaviota (N2) $\left(43^{\circ} 25^{\prime} 88^{\prime \prime} \mathrm{N}, 2^{\circ} 50^{\prime} 07^{\prime \prime} \mathrm{W}\right)$ and Ondarroa (N3) (4319'80'N , 2 $\left.25^{\prime} 28^{\prime \prime} \mathrm{W}\right)$. The NW-facing locations

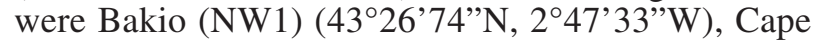
Ogoño (NW2) (43 $\left.26^{\circ} 20^{\prime \prime} \mathrm{N}, 2^{\circ} 56^{\prime} 85^{\prime \prime} \mathrm{W}\right)$ and Cape Lekeitio (NW3) (4322'62'N, 2 $36^{\circ}$ '93”W).

In order to test the influence of light availability on the distribution of epiphytic flora, two depths (3 and $7 \mathrm{~m}$ ) were selected as representative of two different conditions of light intensity. We assumed depth to be a good proxy for light because we only focused on vegetation growing on reefs with slight to moderate slopes $\left(0-30^{\circ}\right)$, thus avoiding the influence of topography at each sampling depth. These two depths were selected according to Díez et al. (2003) who reported that $G$. corneum stands exhibited the highest coverage up to 8 m depth for our study area.

The sampling was conducted in summer 2008. At each depth three replicates of $50 \times 50 \mathrm{~cm}$ quadrats were randomly sampled. Those G. corneum fronds and their epiphytes inside the quadrats were removed by carefully scraping the substrate; fronds were placed in labelled cotton bags and transferred later to the laboratory in wet conditions.

Once in the laboratory, samples were kept frozen. For the analysis, samples were thawed and the epiphytic flora was separated and identified. Algal taxonomy was updated following AlgaeBase (Guiry and Guiry 2014). Subsequently, the dry weight values $\left(100-110^{\circ} \mathrm{C}, 24 \mathrm{~h}\right)$ were obtained for G. corneum and its epiphytes.

\section{Statistical analysis}

The surface that could be epiphytized differed in each sample according to the variation in abundance of the host G. corneum (Table 1). Therefore, a standardization was performed to compare epiphyte abundances from different samples. This was achieved by obtaining the epiphyte/G. corneum biomass ratio for every taxon at each sampling unit.

Univariate and multivariate analyses were conducted using the PERMANOVA+ for PRIMER6 package (Anderson et al. 2008). For each sampling unit, community measures including species richness (S), Shannon diversity $\left(H^{\prime}, \log _{e}\right)$, Simpson $(1-\lambda)$ diversity and Pielou J' evenness were calculated. Spatial differences in community measures and multivariate structure (i.e. quali-quantitative taxa composition) of epiphytic flora on $G$. corneum were tested with an a priori chosen significance level of $\alpha=0.05$. The experimental design consisted of three factors: coastal orientation (OR; 2 levels, fixed), location (LO; 6 levels, random) and depth (DE; 2 levels, fixed, crossed with coastal orientation and location). Univariate analyses were based on Euclidean distance, whereas multivariate analyses were based on the Bray-Curtis similarity matrix calculated from fourth root transformed data. After relevant terms, post hoc pairwise comparisons were performed using PERMANOVA t statistics and 9999 permutations. Homogeneity within each factor was explored by applying the permutational test for homogeneity of multivariate dispersions (PERMDISP). A principal coordinate analysis (PCO) was conducted to visualize the sample grouping in two-dimensional space and to calculate how much of the variability in taxa compo-

Table 1. - Biomass of G. corneum (mean \pm se, g dry weight $0.25 \mathrm{~m}^{-2}$ ) in relation to coastal orientation (N, north; NW, northwest), location and depth.

\begin{tabular}{lccccc}
\hline & & N-facing locations & \multicolumn{3}{c}{ NW-facing locations } \\
(depth) & $\mathrm{N} 1$ & $\mathrm{~N} 2$ & $\mathrm{~N} 3$ & $\mathrm{NW}$ & $\mathrm{NW}$ \\
\hline $3 \mathrm{~m}$ & $5.67 \pm 0.26$ & $4.65 \pm 0.41$ & $3.68 \pm 0.64$ & $24.13 \pm 3.67$ & $16.75 \pm 3.86$ \\
$7 \mathrm{~m}$ & $13.15 \pm 1.64$ & $15.64 \pm 1.12$ & $11.49 \pm 1.81$ & $180.53 \pm 18.99$ & $60.72 \pm 3.75$ \\
\hline
\end{tabular}


Table 2. - Epiphytic taxa and their families recorded growing on G. corneum during the study period (2008). Taxa are arranged by abundances.

\begin{tabular}{ll}
\hline Taxa & Family \\
\hline Plocamium cartilagineum (Linnaeus) P.S. Dixon & Plocamiaceae \\
Dictyota dichotoma (Hudson) J.V. Lamouroux & Dictyotaceae \\
Acrosorium ciliolatum (Harvey) H. Kylin & Delesseriaceae \\
Falkenbergia rufolanosa (Harvey) F. Schmitz (tetrasporic phase of Asparagopsis armata) & Bonnemaisoniaceae \\
Bonnemaisonia hamifera P. Hariot & Bonnemaisoniaceae \\
Aglaothamnion tripinnatum (Agardh) G. Feldmann-Mazoyer & Callithamniaceae \\
Aglaothamnion tenuissimum (Bonnemaison) G. Feldmann-Mazoyer & Callithamniaceae \\
Gayliella flaccida (Harvey ex Kützing) T.O. Cho and L.J. Mclvor & Ceramiaceae \\
Trailliella intricata (tetrasporic phase of B. hamifera) & Bonnemaisoniaceae \\
Antithamnionella ternifolia (Hooker and Harvey) L. Lyle & Ceramiaceae \\
Callithamnion tetragonum (Withering) S.F. Gray & Callithamniaceae \\
Antithamnion nipponicum Y. Yamada and K. Inagaki & Ceramiaceae \\
\hline
\end{tabular}

sition and abundance was explained by the first two axes. The vectors of the taxa abundances were overlaid onto the PCO using Spearman correlation. The contribution of each epiphytic taxon to the separation of the three groups detected in the pairwise comparisons was examined using the similarity percentage procedure (SIMPER).

\section{RESULTS}

A total of 12 macroalgae taxa were recorded growing over G. corneum, most of them being morphologically simple forms belonging to the Ceramiaceae, Callithamniaceae and Bonnemaisoniaceae families (Table 2). The total epiphytes/G. corneum biomass ratio was higher at $\mathrm{N}$-facing locations than at $\mathrm{NW}$-facing locations (Fig. 2). However, differences in relation to depth were only found at $\mathrm{N}$-facing locations, with the total epiphytes $/ G$. corneum biomass ratio being higher at $3 \mathrm{~m}$ depth (Fig. 2). In this regard, univariate PERMANOVA analyses detected a significant interaction between coastal orientation and depth (Pseudo$\left.\mathrm{F}_{1,4}=42.31, \mathrm{p}=0.004\right)$. With respect to species richness (Fig. 3A), the number of taxa in $\mathrm{N}$-facing locations
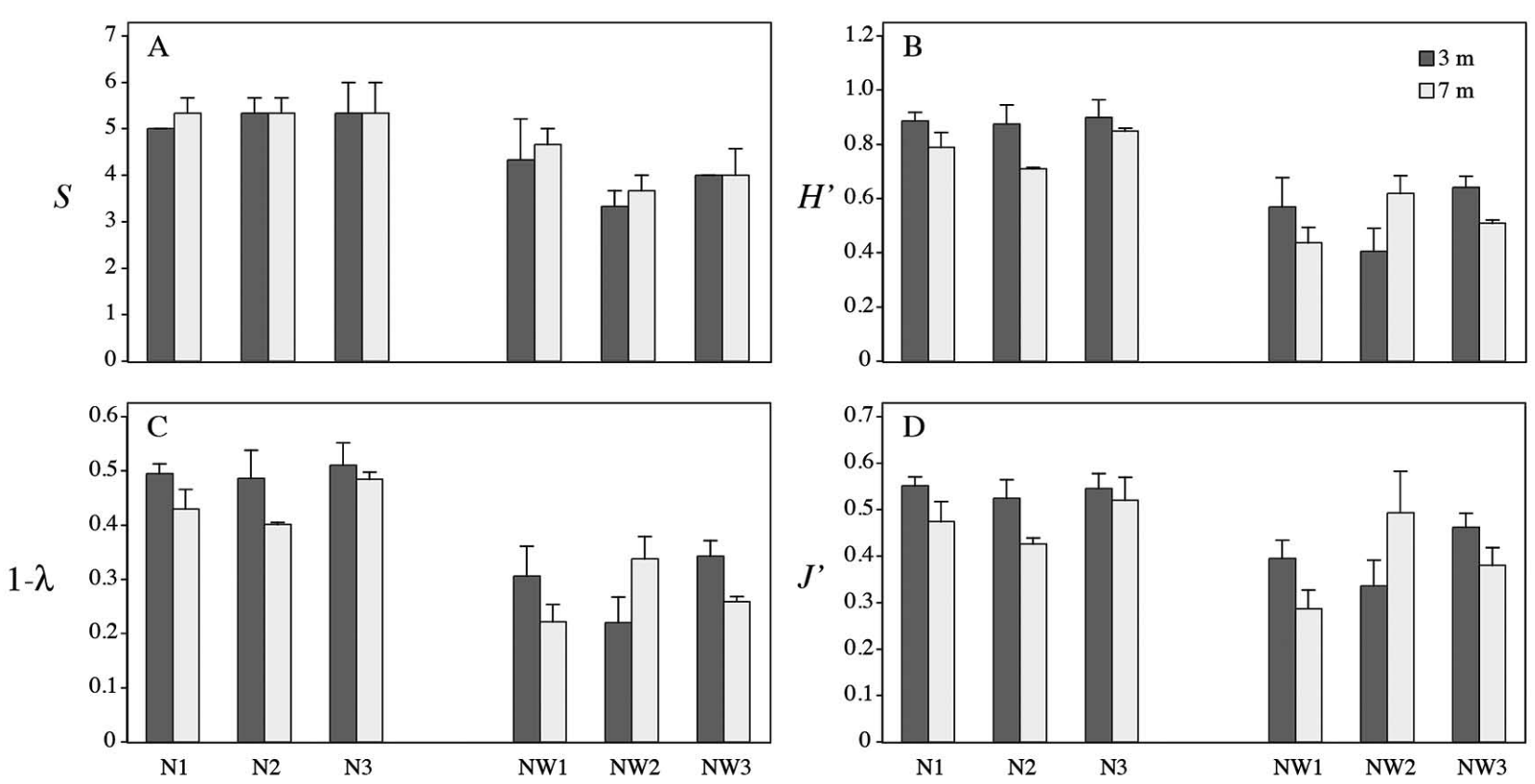

ig. 2. - Plot showing the interactive effect of coastal orientation (North: N1, N2, N3; Northwest: NW1, NW2, NW3) and depth (3 and $7 \mathrm{~m}$ ) on total epiphytes/Gelidium biomass ratio $\left(0.25 \mathrm{~m}^{2}\right)$. Bars represent means \pm se $(n=3)$.

was significantly higher than in NW-facing locations (Pseudo- $\mathrm{F}_{1,4}=18.89, \mathrm{p}=0.013$ ). Diversity also differed from one coastal orientation to the other. Both Shannon (Fig. 3B) and Simpson (Fig. 3C) diversities were significantly higher at $\mathrm{N}$-facing locations (Pseudo$\mathrm{F}_{1,4}=87.43, \mathrm{p}=0.001$ and Pseudo- $\mathrm{F}_{1,4}=96.09, \mathrm{p}=0.001$, respectively). Finally, Pielou J' evenness (Fig. 3D) was

Fig. 3. - Species richness (A), Shannon diversity (B) Simpson diversity (C) and Pielou J' evenness (D) of epiphytic flora in relation to coastal orientation (North: N1, N2, N3; Northwest: NW1, NW2, NW3) and depth (3 and $7 \mathrm{~m})$. Bars represent means \pm se (n=3). 


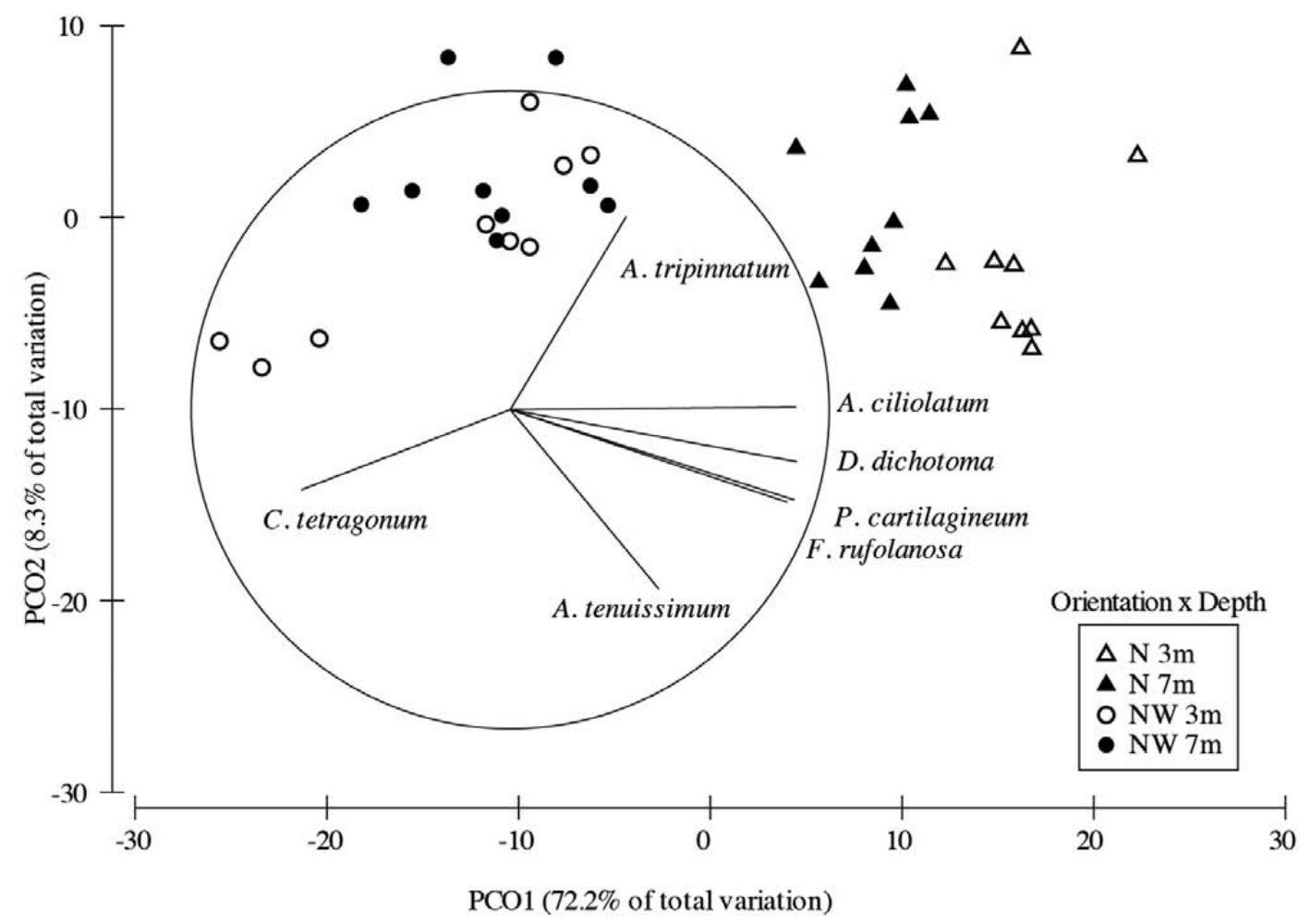

Fig. 4. - PCO diagram based on Bray-Curtis dissimilarities showing sample distribution in relation to the interaction between coastal orientation (triangles: N; circles: NW) and depth (white, $3 \mathrm{~m}$; black, $7 \mathrm{~m}$ ). Variables were fourth-root transformed and the vector overlay (Spearman rank correlation $>0.5$ ) indicates the relationship between taxa and PCO axes.

also higher at $\mathrm{N}$-facing locations (Pseudo- $\mathrm{F}_{1,4}=13.79$, $\mathrm{p}=0.027)$. In all cases depth showed no effect on community measures.

Principal coordinates analysis (PCO) relates the pattern of distribution of samples to the macroalgae taxa recorded as G. corneum epiphytes (Fig. 4). PCO axis 1 , which explained $72.2 \%$ of the total variation, mainly reflected differences related to the interaction between coastal orientation and depth. The points for the samples collected at NW-facing locations, at depths of both 3 and $7 \mathrm{~m}$, are located towards the left of the plot, whereas the samples collected at Nfacing locations are placed towards the right, where samples collected at 3 and $7 \mathrm{~m}$ are separated. Indeed, PERMANOVA analyses on multivariate data detected a significant interaction between coastal orientation and depth (Table 3). Pairwise comparisons indicated that epiphytic abundance and composition at 3 and $7 \mathrm{~m}$ was significantly different within $\mathrm{N}$-facing locations, whereas no differences were found between epiphytes from the two depths at NW-facing locations. Therefore, three different groups were distinguished: Group $1(\mathrm{~N} ; 3 \mathrm{~m})$, Group $2(\mathrm{~N} ; 7 \mathrm{~m})$ and Group $3(\mathrm{NW})$. The two-dimensional projection is highly representative of the full data cloud since it explains $80.5 \%$ of the total variation. Spearman correlations show that $P$. cartilagineum, D. dichotoma, Acrosorium ciliolatum and Falkenbergia rufolanosa are positively correlated with PCO axis 1, whereas Callithamnion tetragonum has a negative relationship (Fig. 4).

The SIMPER routine identified Group 3 (NW) as the most distinctive group, with average dissimilarities
Table 3. - Summary of PERMANOVA results testing for the effect of coastal orientation (OR), location (LO) and depth (DE) on the composition and abundance (biomass ratios) of the epiphytic taxa growing on G. corneum (ns=non significant, $*<0.05, * *<0.01$, $* * *<0.001$ ). Pairwise comparisons for the $\mathrm{OR} \times \mathrm{DE}$ interaction are shown.

\begin{tabular}{lrrrl}
\hline \multicolumn{2}{l}{ PERMANOVA results } & \multicolumn{1}{c}{ MS } & Pseudo-F & $\mathrm{p}$ \\
\hline OR & 1 & 11233.02 & 47.96 & $* * *$ \\
DE & 1 & 1145.41 & 4.83 & $*$ \\
LO (OR) & 4 & 234.17 & 1.14 & $\mathrm{~ns}$ \\
OR $\times$ DE & 1 & 680.48 & 3.62 & $*$ \\
LO (OR) $\times$ DE & 4 & 237.11 & 1.16 & $\mathrm{~ns}$ \\
Error & 24 & 204.08 & & \\
\hline
\end{tabular}

Pairwise comparisons:

$\mathrm{N} 3 \mathrm{~m}>\mathrm{N} 7 \mathrm{~m}>\mathrm{NW} 3 \mathrm{~m}=\mathrm{NW} 7 \mathrm{~m}$

of $31.11 \%$ and $24.35 \%$ with respect to Group $1(\mathrm{~N} ; 3$ $\mathrm{m})$ and Group $2(\mathrm{~N} ; 7 \mathrm{~m})$, respectively (Table 4). This procedure identified $P$. cartilagineum, $D$. dichotoma, A. ciliolatum and $F$. rufolanosa as the species which contributed most to the dissimilarities between Group 3 and the other two groups (Table 4). In the case of the dissimilarity between Group 1 and Group 2, the contribution of A. tenuissimum and A. tripinnatum was also relevant. Regarding the abundance of different taxa, $P$. cartilagineum, D. dichotoma, and A. ciliolatum showed the highest biomass ratios in all the groups whereas other taxa only appeared in one group: Trailliella intricata (Group 1), Antithamnionella ternifolia (Group 2), C. tetragonum and Antithamnion nipponicum (Group 3) (Table 5). Group 1 registered the highest biomass ratios for most taxa, which decreased gradually towards Groups 2 and 3. 
Table 4. - Summary of SIMPER procedure indicating the dissimilarity between Group 1 (N; 3 m), Group 2 (N; 7 m) and Group 3 (NW), and the contribution $(\%)$ of each taxon.

\begin{tabular}{|c|c|c|c|c|c|}
\hline \multicolumn{2}{|c|}{$\begin{array}{c}\text { Group } 1 \text { and Group } 2 \\
(\text { Av. Dissimilarity=14.97\%) }\end{array}$} & \multicolumn{2}{|c|}{$\begin{array}{c}\text { Group } 1 \text { and Group } 3 \\
\text { (Av. Dissimilarity=31.11\%) }\end{array}$} & \multicolumn{2}{|c|}{$\begin{array}{c}\text { Group } 2 \text { and Group } 3 \\
\text { (Av. Dissimilarity=24.35\%) }\end{array}$} \\
\hline Taxa & Contr. (\%) & Taxa & Contr. (\%) & Taxa & Contr. (\%) \\
\hline A. ciliolatum & 19.0 & F. rufolanosa & 21.8 & F. rufolanosa & 25.6 \\
\hline P. cartilagineum & 13.7 & A. ciliolatum & 20.1 & D. dichotoma & 17.5 \\
\hline A. tenuissimum & 12.3 & D. dichotoma & 19.0 & A. ciliolatum & 14.0 \\
\hline D. dichotoma & 12.0 & P. cartilagineum & 13.8 & P. cartilagineum & 8.6 \\
\hline A. tripinnatum & 11.5 & A. tenuissimum & 6.5 & A. tripinnatum & 7.6 \\
\hline A. ternifolia & 8.6 & C. tetragonum & 4.7 & A. ternifolia & 7.2 \\
\hline G. flaccida & 7.8 & G. flaccida & 3.5 & C. tetragonum & 6.7 \\
\hline
\end{tabular}

Table 5. - Average abundance (epiphytes/G. corneum biomass ratios) of each taxon in the different groups (Group 1, Group 2, Group 3). Taxa are arranged by abundances.

\begin{tabular}{lrrr}
\hline & $\begin{array}{r}\text { Group 1 } \\
(\mathrm{N3m})\end{array}$ & $\begin{array}{r}\text { Group 2 } \\
(\mathrm{N7m})\end{array}$ & $\begin{array}{r}\text { Group 3 } \\
(\mathrm{NW})\end{array}$ \\
Taxa & Av. Abund. & Av. Abund. & Av. Abund. \\
\hline P. cartilagineum & 0.230012 & 0.142005 & 0.093562 \\
D. dichotoma & 0.077107 & 0.044609 & 0.012694 \\
A. ciliolatum & 0.040558 & 0.011547 & 0.007273 \\
F. rufolanosa & 0.003253 & 0.001696 & 0.000151 \\
B. hamifera & 0.000973 & 0 & 0.000287 \\
A. tripinnatum & 0.000702 & 0.000304 & 0.000048 \\
A. tenuissimum & 0.000561 & 0.000186 & 0 \\
G. flaccida & 0.000344 & 0.000255 & 0 \\
T. intricata & 0.000341 & 0 & 0 \\
A. ternifolia & 0 & 0.000221 & 0 \\
C. tetragonum & 0 & 0 & 0.000178 \\
A. nipponicum & 0 & 0 & 0.000052 \\
\hline
\end{tabular}

\section{DISCUSSION}

We expected the abundance and diversity of epiphytes to be negatively correlated with wave exposure (coastal orientation) and positively correlated with light intensity (negatively with depth). Our results partially support this hypothesis. Significant interactive effect of these two factors was observed for species composition and abundance of epiphytic flora. G. corneum populations living at the most exposed locations had the lowest epiphyte load and the least diverse community. However, depth only had a significant effect on the distribution of epiphytes below a certain threshold of wave action, with the epiphytic load being $30-40 \%$ greater on shallow bottoms. This pattern suggests that in shallow waters hydrodynamic pressure on epiphytic flora could be a more determinant factor in regulating epiphytes than light availability.

The composition of epiphytes on G. corneum is found to be dominated by $P$. cartilagineum, $D$. dichotoma and A. ciliolatum. The first two of these taxa have been described as common annual epiphytes accompanying G. corneum (Santos 1994, Gorostiaga 1995). Furthermore, hydrodynamism appeared to have a significant influence on the distribution of some morphologically simple taxa, whereas $F$. rufolanosa, A. tenuissimum, A. tripinnatum, A. ternifolia, and G. flaccida showed a preference for relatively lower-energy conditions, C. tetragonum and the alien species A. nipponicum were more abundant at the most exposed locations. It is also noteworthy that the epiphytic community on G. corneum found in this study was extraordinary low, especially compared with that found in northwestern Spain (Galicia) for other canopy-forming species thriving in semiexposed to exposed areas (Otero-Schmitt and PérezCirera 1996). The latter authors found 30 to 70 different species of epiphytic flora, mainly rhodophytes, growing in four different species from the genus Cystoseira. In this sense, the frondose morphology and cartilaginous texture of $G$. corneum contrasts with the tree-like morphology and leathery texture of the species of the genus Cystoseira, which might enhance the notable differences found in the diversity of epiphytic flora between the two macrophytes. Differences in epiphytic loads regarding morphological features and longevity of the host have been reported in the case of seagrass species (Lavery and Vanderklift 2002).

With respect to the epiphytic loads in the present study, very exposed (NW) areas showed significantly lower epiphytic abundances than exposed $(\mathrm{N})$ areas. This pattern is consistent with other studies from northwestern Spain (Galicia) (Peteiro and Freire 2013) and northern Europe (Pedersen et al. 2012, Baer and Stengel 2014), which found the epiphytic loads on canopyforming species to be lower on more exposed coastal stretches. Moreover, very exposed locations (NW) in our study showed lower species richness and diversity, coinciding with that found for epiphytic flora (Kersen et al. 2011) and fauna growing on canopy-forming macrophytes (Norderhaug et al. 2012, 2014), according to whom lower species diversities are found under frequent or even rare ecological disturbances (e.g. wave action). Indeed, wave exposure is one of the major factors directly or indirectly influencing the structure of algal assemblages (Rindi and Guiry 2004, Nishihara and Terada 2010, Borja et al. 2013). Although increasing wave action is a key factor in supplying nutrients for macroalgae (Martins et al. 2013), hydrodynamic pressure can also remove epibionts and prevent them from settling (Kersen et al. 2011). The mechanical stress produced by higher wave-action (Kraufvelin 2007) could favour the removal of epiphytes at NW oriented locations in our study, whereas at $\mathrm{N}$ oriented locations lower hydrodynamic levels could favour their development. Similarly, the lower species richness and diversity and the smaller quantities of morphologically simple forms found at NW-facing locations in this study might be explained by the higher sensitivity of some taxa to the effects of wave action (Nishihara and Terada 2010). However, there are some exceptions, such as $C$. tetragonum and A. nipponicum, which showed affinity to more exposed coastal stretches, as also reported by Secilla (2009). 
Light is a prime factor regulating the distribution of algae since the survival and productivity of photosynthetic organisms are closely linked to light intensity and quality (Prado et al. 2007, Michael et al. 2008). Increasing irradiance levels usually favour algal development and growth (Altamirano et al. 2000, ColomboPallotta et al. 2006). Therefore, due to the exponential decay of light intensity with increasing depth (Gross et al. 2003, Martins et al. 2013), shallower waters may be expected to contain higher epiphyte loads (Muñoz and Fotedar 2010, Tsirika et al. 2007). Our findings partially support this hypothesis. At the $\mathrm{N}$-facing locations (with less wave energy) the epiphytic load was significantly greater in shallow waters than in deeper waters. However, our results do not show this pattern in the NW-facing locations, where the potentially greater epiphytic growth under high light conditions may be mitigated by the higher wave action (Liria et al. 2009, Galparsoro et al. 2010). Nevertheless, it should be noted that factors other than light, such as water movement, temperature, sedimentation and nutrient availability, may vary with depth. Therefore, experimental field and laboratory studies should be conducted in order to separate the effect of light availability on the distributional patterns of epiphytes from other depthrelated factors.

In conclusion, our findings suggest that the interactive effects of wave action and light availability seem to be involved in the diversity, abundance and composition patterns of the epiphytes growing on G. corneum. Since epiphytes may cause some damage to their hosts, future field and laboratory experiments should be carried out to assess the effects of these assemblages on G. corneum populations. Furthermore, considering the significant decline undergone by G. corneum in pristine coastal stretches of the Basque coast (Díez et al. 2012, Borja et al. 2013), the combined effects of epiphytism and potential environmental stressors on this canopyforming species would need to be separated to generate better predictive models of the distribution of $G$. corneum under hypothetical climate change scenarios.

\section{ACKNOWLEDGEMENTS}

This study was supported by the projects 'ECOLIFE-CAN: Monitoring the Effects of Climate Change on Benthic Marine Communities along the Basque Coast: a First Evaluation of Biological (CGL08-0547) and Ecological Changes and Stress Factors' (Ministry of Science and Innovation, MICIIN) and 'K-EGOKITZEN: Climate Change: Impact and Adaptation' (Department of Industry, Trade and Tourism of the Basque Government). We are also indebted to the University of the Basque Country (UPV/EHU) for grant PIF09/2009/PIF09048, which partially supported this work.

\section{REFERENCES}

Altamirano M., Flores-Moya A., Figueroa F.L. 2000. Long-term effect of natural sunlight under various ultraviolet radiation conditions on growth and photosynthesis of intertidal Ulva rigida (Chlorophyceae) cultivated in situ. Bot. Mar. 43: 119-126.
http://dx.doi.org/10.1515/BOT.2000.012

Anderson L.M., Martone P.T. 2014. Biomechanical consequences of epiphytism in intertidal macroalgae. J. Exp. Biol. 217: $1167-1174$ http://dx.doi.org/10.1242/jeb.088955

Anderson M.J., Gorley R.N., Clarke K.R. 2008. PERMANOVA+ for PRIMER: Guide to Software and Statistical Methods. PRIMER-E, Plymouth, 214 pp.

Baer J., Stengel D.B. 2014. Can native epiphytes affect establishment success of the alien seaweed Sargassum muticum (Phaeophyceae)? Biol. Environ. 114B: 41-52. http://dx doi.org/10.3318/bioe 2014.05

Belegratis M.R., Bitis I., Economou-Amilli J.A., et al. 1999. Epiphytic patterns of macroalgal assemblages on Cystoseira species (Fucales, Phaeophyta) in the east coast of Attica (Aegean Sea, Greece). Hydrobiologia 412: 67-80. http://dx.doi.org/10.1023/A:1003852300198

Borja A., Aguirrezabalaga F., Martínez J., et al. 2004. Benthic communities, biogeography and resources management. In: Borja A., Collins M. (eds), Oceanography and Marine Environment of the Basque Country. Elsevier, Amsterdam, pp. 455-492. http://dx.doi.org/10.1016/S0422-9894(04)80056-4

Borja A., Fontán A., Muxika I. 2013. Interactions between climatic variables and human pressures upon a macroalgae population: Implications for management. Ocean Coast. Manage. 76: 85-95. http://dx.doi.org/10.1016/j.ocecoaman.2013.02.023

Bustamante M., Tajadura J., Gorostiaga J.M., et al. 2014. Response of rocky invertebrate diversity, structure and function to the vertical layering of vegetation. Est. Coast. Shelf Sci. 147: 148-155. http://dx.doi.org/10.1016/j.ecss.2014.06.001

Chust G., Borja A., Caballero A., et al. 2011. Climate change impacts on coastal and pelagic environments in the southeastern Bay of Biscay. Clim. Res. 48: 307-332. http://dx.doi.org/10.3354/cr00914

Colombo-Pallotta M.F., Garcia-Mendoza E., Ladah L.B. 2006. Photosynthetic performance, light absorption, and pigment composition of Macrocystis pyrifera (Laminariales, Phaeophyceae) blades from different depths. J. Phycol. 42: 1225-1234. http://dx.doi.org/10.1111/j.1529-8817.2006.00287.x

Díez I., Santolaria A., Gorostiaga J.M. 2003. The relationship of environmental factors to the structure and distribution of subtidal seaweed vegetation of the western Basque coast (N Spain). Est. Coast. Shelf Sci. 56: 1041-1054. http://dx.doi.org/10.1016/S0272-7714(02)00301-3

Díez I., Muguerza N., Santolaria S., et al. 2012. Seaweed assemblage changes in the eastern Cantabrian Sea and their potential relationship to climate change. Estuar. Coast. Shelf Sci. 99: $108-120$. http://dx.doi.org/10.1016/j.ecss.2011.12.027

Fricke A., Titlyanova T.V., Nugues M.M., et al. 2011. Depth-related variation in epiphytic communities growing on the brown alga Lobophora variegata in a Caribbean coral reef. Coral Reefs 30: 967-973. http://dx.doi.org/10.1007/s00338-011-0772-0

Galparsoro I., Borja A., Legorburu I., et al. 2010. Morphological characteristics of the Basque continental shelf (Bay of Biscay, northern Spain); their implications for Integrated Coastal Zone Management. Geomorphology 118: 314-329. http://dx.doi.org/10.1016/j.geomorph.2010.01.012

Giovannetti E., Montefalcone M., Morri C., et al. 2010. Early warning response of Posidonia oceanica epiphyte community to environmental alterations (Ligurian Sea, NW Mediterranean). Mar. Pollut. Bull. 60: 1031-1039. http://dx.doi.org/10.1016/j.marpolbul.2010.01.024

González M., Uriarte A., Fontán A., et al. 2004. Marine dynamics. In: Borja A., Collins M. (eds), Oceanography and Marine Environment of the Basque Country. Elsevier, Amsterdam, pp. $133-157$ http://dx.doi.org/10.1016/S0422-9894(04)80044-8

Gorostiaga J.M. 1994. Growth and production of the red alga $\mathrm{Ge}$ lidium sesquipedale off the Basque coast (northern Spain). Mar. Biol. 120: 311-322 http://dx.doi.org/10.1007/BF00349693

Gorostiaga J.M. 1995. Sublittoral seaweed vegetation in a very exposed shore on the Basque Coast (N. Spain). Bot. Mar. 38: 9-16. http://dx.doi.org/10.1515/botm.1995.38.1-6.9

Gorostiaga J.M., Santolaria A., Secilla A., et al. 1998. Sublittoral benthic vegetation of the eastern Basque coast (N. Spain): Structure and environmental factors. Bot. Mar. 41: 455-465. http://dx.doi.org/10.1515/botm.1998.41.1-6.455 
Gross E.M., Feldbaum C., Graf A. 2003. Epiphyte biomass and elemental composition on submersed macrophytes in shallow eutrophic lakes. Hydrobiologia 506-509: 559-565. http://dx.doi.org/10.1023/B:HYDR.0000008538.68268.82

Guiry M.D., Guiry G.M. 2014. AlgaeBase. World-wide electronic publication, National University of Ireland, Galway. http://www.algaebase.org.

Karez R., Engelbert S., Sommer U. 2000. 'Co-consumption' and 'protective coating': two new proposed effects of epiphytes on their macroalgal hosts in mesograzer-epiphyte-host interactions. Mar. Ecol. Prog. Ser. 205: 85-93. http://dx.doi.org/10.3354/meps205085

Kersen P., Kotta J., Bucas M., et al. 2011. Epiphytes and associated fauna on the brown alga Fucus vesiculosus in the Baltic and the North Seas in relation to different abiotic and biotic variables. Mar. Ecol. 32: 87-95. http://dx.doi.org/10.1111/j.1439-0485.2010.00418.x

Kraufvelin P. 2007. Responses to nutrient enrichment, wave action and disturbance in rocky shore communities. Aquat. Bot. 87: 262-274. http://dx.doi.org/10.1016/j.aquabot.2007.06.011

Lavery P.S., Vanderklift M.A. 2002. A comparison of spatial and temporal patterns in epiphytic algal assemblages of the seagrasses Amphibolis griffithii and Posidonia coriacea. Mar. Ecol. Prog. Ser. 236: 99-112. http://dx doi.org/10.3354/mens 236099

Liria P., Garel E., Uriarte A. 2009. The effects of dredging operations on the hydrodynamics of an ebb tidal delta: Oka Estuary, northern Spain. Cont. Shelf Res. 29: 1983-1994. http://dx.doi.org/10.1016/j.csr.2009.01.014

Lüning K. 1990. Seaweeds. Their Environment, Biogeography and Ecophysiology. Wiley-Interscience Publication, New York, $527 \mathrm{pp}$.

Lutz M.L., Davis A.R., Minchinton T.E. 2010. Non-indigenous macroalga hosts different epiphytic assemblages to conspecific natives in southeast Australia. Mar. Biol. 157: 1095-1103. http://dx.doi.org/10.1007/s00227-010-1391-y

Martins G.M., Patarra R.F., Álvaro N.V., et al. 2013. Effects of coastal orientation and depth on the distribution of subtidal benthic assemblages. Mar. Ecol. 34: 289-297. http://dx.doi.org/10.1111/maec.12014

McHugh D.J. 1991. Worldwide distribution of commercial resources of seaweeds including Gelidium. Hydrobiologia 221: 19-29. http://dx.doi.org/10.1007/BF00028359

Michael T.S., Shin H.W., Hanna R., et al. 2008. A review of epiphyte community development: Surface interactions and settlement on seagrass. J. Environ. Biol. 24: 629-638.

Muñoz J., Fotedar R. 2010. Epiphytism of Gracilaria cliftonii (Withell, Millar and Kraft) from Western Australia. J. Appl. Phycol. 22: 371-379. http://dx.doi.org/10.1007/s10811-009-9469-y

Muñoz J., Cancino J.M., Molina M.X. 1991. Effect of encrusting bryozoans on the physiology of their algal substratum. J. Mar. Biol. Assoc. UK 7: 877-882.

Nishihara G.N., Terada R. 2010. Species richness of marine macrophytes is correlated to a wave exposure gradient. Phycol. Res. 58: 280-292. http://dx.doi.org/10.1111/j.1440-1835.2010.00587.x

Norderhaug K.M., Christie H., Andersen G.S., et al. 2012. Does the diversity of kelp forest macrofauna increase with wave exposure? J. Sea Res. 69: 36-42. http://dx.doi.org/10.1016/j.seares.2012.01.004

Norderhaug K.M., Christie H., Rinde E., et al. 2014. Importance of wave and current exposure to fauna communities in Laminaria hyperborea kelp forests. Mar. Ecol. Prog. Ser. 502: 295-301. http://dx.doi.org/10.3354/meps 10754

Otero-Schmitt J., Pérez-Cirera J.L. 1996. Epiphytism on Cystoseira (Fucales, Phaeophyta) from the Atlantic Coast of Northwest Spain. Bot. Mar. 39: 445-465. http://dx.doi.org/10.1515/botm.1996.39.1-6.445

Pedersen M.F., Nejrup L.B., Fredriksen S., et al. 2012. Effects of wave exposure on population structure, demography, biomass and productivity of the kelp Laminaria hyperborean. Mar. Ecol. Prog. Ser. 451: 45-60. http://dx.doi.org/10.3354/meps09594

Peteiro C., Freire O. 2013. Epiphytism on blades of the edible kelps Undaria pinnatifida and Saccharina latissima farmed under different abiotic conditions. J. World Aquacult. Soc. 44(5): 706-715. http://dx.doi.org/10.1111/jwas. 12065

Prado P., Alcoverro T., Martinez-Crego B., et al. 2007. Macrograzers strongly influence patterns of epiphytic assemblages in seagrass meadows. J. Exp. Mar. Biol. Ecol. 350: 130-143. http://dx.doi.org/10.1016/j.jembe.2007.05.033

Quintano E., Ganzedo U., Díez I., et al. 2013. Solar radiation (PAR and UVR) and water temperature in relation to biochemical performance of Gelidium corneum (Gelidiales, Rhodophyta) in subtidal bottoms off the Basque coast. J Sea Res. 83: 47-55. http://dx.doi.org/10.1016/j.seares.2013.05.008

Rico J.M., Fredriksen S. 1996. Effects of environmental factors on net photosynthesis and growth of intertidal species of the genus Gelidium (Gelidiaceae, Rhodophyta) in northern Spain. Sci. Mar. 60: 265-273

Rindi F., Guiry M.D. 2004. Composition and spatio temporal variability of the epiphytic macroalgal assemblage of Fucus vesiculosus Linnaeus at Clare Island, Mayo, western Ireland. J. Exp. Mar. Biol. Ecol. 311: 233-252. http://dx.doi.org/10.1016/j.jembe.2004.05.009

Russell B.D., Elsdon T.S., Gillanders B.M., et al. 2005. Nutrients increase epiphyte loads: broad-scale observations and an experimental assessment. Mar. Biol. 147: 551-558. http://dx.doi.org/10.1007/s00227-005-1571-3

Sand-Jensen K. 1977. Effect of epiphytes on eelgrass photosynthesis. Aquat. Bot. 3: 55-63. http://dx.doi.org/10.1016/0304-3770(77)90004-3

Santos R. 1994. Frond dynamics of the commercial seaweed $G e$ lidium sesquipedale: effects of size and of frond history. Mar. Ecol. Prog. Ser. 107: 295-305. http://dx.doi.org/10.3354/meps 107295

Secilla A. 2009. La familia Ceramiaceae sensu lato en la costa de Bizkaia. Ph.D. Thesis, University of the Basque Country, 324 pp.

Tsirika A., Skoufas G., Haritonidis S. 2007. Seasonal and bathymetric variations of epiphytic macroflora on Posidonia oceanica (L.) Delile leaves in the National Marine Park of Zakynthos (Greece). Mar. Ecol. 28: 146-153. http://dx.doi.org/10.1111/j.1439-0485.2007.00170.x

Wahl M. 1989. Marine epibiosis. I. Fouling and antifouling: some basic aspects. Mar. Ecol. Prog. Ser. 58: 175-189. http://dx.doi.org/10.3354/meps058175 